\title{
Exploiting genetic variability in the trajectory of lactation yield and somatic cell score with each progressing parity
}

\author{
M. Williams, ${ }^{1,2} \odot$ R. D. Sleator, ${ }^{2} \odot$ C. P. Murphy, ${ }^{2} \odot$ J. McCarthy, ${ }^{3}$ and D. P. Berry ${ }^{1 *} \odot$ \\ ${ }^{1}$ Department of Animal Bioscience, Animal and Grassland Research and Innovation Centre, Teagasc, Moorepark, Fermoy, Co. Cork, \\ Ireland P61 C996 \\ ${ }^{2}$ Department of Biological Sciences, Munster Technological University, Bishopstown Campus, Co. Cork, Ireland T12 P928 \\ ${ }^{3}$ Irish Cattle Breeding Federation, Highfield House, Bandon, Co. Cork, Ireland P72 X050
}

\begin{abstract}
The inclusion of reproductive performance in dairy cow breeding schemes has resulted in a cumulative improvement in genetic merit for reproductive performance; this improvement should manifest in longer productive lives through a reduced requirement for involuntary culling. Nonetheless, the average length of dairy cow productive life has not changed in most populations, suggesting that risk factors for culling, especially in older cows, are possibly more associated with lower yield or high somatic cell score (SCS) than compromised reproductive performance. The objective of the present study was to understand the dynamics of lactation yields and SCS in dairy cows across parities and, in doing so, quantify the potential to alter this trajectory through breeding. After edits, 3,470,520 305$\mathrm{d}$ milk, fat, and protein yields, as well as milk fat and protein percentage and somatic cell count records from $1,162,473$ dairy cows were available for analysis. Random regression animal models were used to identify the parity in which individual cows reached their maximum lactation yields, and highest average milk composition and SCS; also estimated from these models were the (co)variance components for yield, composition, and SCS per parity across parities. Estimated breeding values for all traits per parity were calculated for cows reaching $\geq$ fifth parity. Of the cows included in the analyses, $91.0 \%, 92.2 \%$, and $83.4 \%$ reached maximum milk, fat, and protein yield in fifth parity, respectively. Conversely, $95.9 \%$ of cows reached their highest average fat percentage in first parity and $62.9 \%$ of cows reached their highest average protein percentage in third parity. In contrast to both milk yield and composition traits, $98.4 \%$ of cows reached their highest average SCS in eighth parity. Individual parity estimates of heritability for milk yield traits, milk composition, and SCS
\end{abstract}

Received September 17, 2021.

Accepted December 9, 2021.

*Corresponding author: donagh.berry@teagasc.ie ranged from 0.28 to $0.44,0.47$ to 0.69 , and 0.13 to 0.23 , respectively. The strength of the genetic correlations per trait among parities was inversely related to the interval between the parities compared; the weakest genetic correlation was 0.67 (standard error $=0.02$ ) between milk yield in parities 1 and 8. Eigenvalues and eigenfunctions of the additive genetic covariance matrices for all investigated traits revealed potential to alter the trajectory of parity profiles for milk yield, milk composition, and SCS. This was further demonstrated when evaluating the trajectories of animal estimated breeding values per parity.

Key words: maturity, milk, somatic cell score, trajectory

\section{INTRODUCTION}

The inclusion of functional traits, like reproductive performance, in dairy cow breeding programs has contributed to a cumulative improvement in the genetic merit for reproductive performance in most dairy cow populations (Berry et al., 2014; Cole and VanRaden, 2018; De Vries, 2020). The improvement achieved in genetic merit for reproductive performance should have manifested itself in a longer dairy cow productive life via reduced involuntary culling for reproductive failure. Yet, the expected improvements in productive life have not been realized in many populations with the average productive lifespan of a dairy cow remaining between 2.5 and $4.5 \mathrm{yr}$ (Adamczyk et al., 2016; Kerslake et al., 2018; De Vries and Marcondes, 2020). As the improvement in reproductive performance leads to a reduced need for involuntary culling due to reproductive failure, risk factors for culling are therefore likely transitioning from involuntary to voluntary causes. Poor lactation yield and high SCC are already 2 of the primary reasons reported for voluntary culling in dairy cows (Berry et al., 2005; Kerslake et al., 2018; De Vries and Marcondes, 2020) and the rate of culling due to high SCC will likely increase as European dairy producers are required to implement selective dry cow therapy 
from 2022 (Animal Health Ireland; 2020). Therefore, age-linked reductions in lactation yield or increases in SCC could potentially explain why productive life has not improved in line with the genetic gain in reproductive performance.

No study has, to date, specifically investigated the parity at which individual dairy cows reach maximum 305-d milk yield, highest average SCS, or indeed, whether interanimal variability exists in the rate of change in lactation yield or SCS before and after maximum yield or highest average SCS. Nonetheless, based on the documented 305-d milk yield per parity reported by Guo et al. (2002) and Yang et al. (2005), it can be assumed that dairy cows, on average, reach maximum lactation yield in the fourth or fifth parity. Using such mean values to assume the parity at which maximum yield occurs ignores the potential interanimal variability in when maximum lactation yield is achieved.

Although previous studies on dairy cows have reported heritability estimates and genetic (co)variances of 305-d milk yield (Carlén et al., 2004; Yang et al., 2005; Frioni et al., 2017) and SCS per parity (Carlén et al., 2004), no study has estimated the genetic (co) variances among milk yield traits, milk composition, or SCS in dairy cows across a wide range of parities (i.e., first to eighth parity). Estimated 305-d milk yields up to sixth parity have been reported as moderately heritable (0.23 to 0.34; Carlén et al., 2004; Yang et al., 2005; Frioni et al., 2017), and the heritability of SCS has been reported as between 0.10 in third parity and 0.14 in first parity (Carlén et al., 2004). Whereas one study reported a relatively large reduction in heritability estimates of milk yield between parities, from 0.34 in first parity to 0.25 and 0.23 in second and third parities, respectively (Carlén et al., 2004), others have reported the heritability estimates of milk yield (Yang et al., 2005; Frioni et al., 2017) and SCS (Carlén et al., 2004) as being similar (i.e., within 0.04) across parities. The strength of the reported genetic and phenotypic correlations between milk yield (Zarnecki et al., 1991; Carlén et al., 2004; Frioni et al., 2017) and SCS (Carlén et al., 2004) across different parities were generally inversely related to the interval between the parities compared. The genetic correlation between 305-d milk yield in first and second parity, first and third parity, and second and third parity in pasture-based Uruguayan dairy cows was $0.93,0.91$, and 0.97 , respectively (Frioni et al., 2017). The genetic correlations between SCS in first and second parity, first and third parity, and second and third parity in Swedish Holstein dairy cows were 0.76, 0.70, and 0.92, respectively (Carlén et al., 2004). The strong genetic correlations between milk yield and SCS in consecutive parities previously reported suggests increasing or decreasing milk yield or SCS in an individual parity would result in a similar increase or decrease in other adjacent parities. Therefore, the objective of the present study was to understand the phenotypic and genetic dynamics of lactation yields and SCS across parities in dairy cows and, in doing so, quantify the potential to alter the trajectory through breeding.

\section{MATERIALS AND METHODS}

Estimated 305-d lactation yields, average milk composition, average SCC, ancestry, and calving date information were extracted from the national database managed by the Irish Cattle Breeding Federation; the 305-d lactation yields, average milk composition, and average SCC were estimated using the standard lactation curve method (Olori and Galesloot, 1999). Since all information was downloaded from a pre-existing national database, it was not necessary to obtain animal ethics committee approval prior to conducting this study.

\section{Data Edits}

Estimated 305-d lactation yields, average fat and protein percentage, and average SCC were available for $1,890,902$ cows $(5,960,955$ lactations $)$, born between 2000 and 2015, inclusive, calving in 15,317 springcalving herds; all cows calved between 2002 and 2019 . Dairy herds were defined as spring-calving if $>70 \%$ of cows calved between the months of January and June, inclusive (Ring et al., 2019). Records where cow parity was $>10$ were discarded, as were the records from cows without a known sire. First-parity cows recorded to have calved younger than $600 \mathrm{~d}$ of age were removed. Furthermore, the median age at calving was calculated for each parity; 897,930 lactation records were discarded where cows calved more than $180 \mathrm{~d}$ before or after the parity median. For all remaining records, age at calving was categorized, within parity, into 6 groups, each $60 \mathrm{~d}$ in duration relative to the parity median age at calving. Lactation average SCC was normalized to SCS by calculating the logarithm, to base 10, of SCC. Individual 305-d milk, fat, and protein yield, fat and protein percentage, and SCS observations more than 3 standard deviations from the parity mean were removed. All data from an entire parity were discarded if one or more traits were missing; 88,960 lactation records were removed. Heterosis and recombination loss coefficients per cow were calculated as described previously by Ring et al. (2018). Heterosis was divided into 12 classes $(0 \%,>0 \%$ and $\leq 10 \%,>10 \%$ and $\leq 20 \%$, 
$>20 \%$ and $\leq 30 \%,>30 \%$ and $\leq 40 \%,>40 \%$ and $\leq 50 \%$, $>50 \%$ and $\leq 60 \%,>60 \%$ and $\leq 70 \%,>70 \%$ and $\leq 80 \%$, $>80 \%$ and $\leq 90 \%,>90 \%$ and $\leq 99 \%$, and $>99 \%$ ). Recombination loss was divided into 7 classes $(0 \%,>0 \%$ and $\leq 10 \%,>10 \%$ and $\leq 20 \%,>20 \%$ and $\leq 30 \%,>30 \%$ and $\leq 40 \%,>40 \%$ and $\leq 50 \%$, and $>50 \%$ ).

Cows were assigned to contemporary groups within herd based on calving dates using the algorithm currently used to generate contemporary groups for the Irish national genetic evaluations (Berry et al., 2013). Cows that calved within $10 \mathrm{~d}$ of each other were initially clustered together within each herd. Where $<10$ cows were clustered together, these cows were joined to an adjacent contemporary group within the same herd until each contemporary group had $\geq 10$ records, with a maximum distance of $60 \mathrm{~d}$ between calving events in the same contemporary group. Records from contemporary groups with $<10$ records were removed. Records were not required in all preceding parities for a lactation record to be retained. Estimated 305-d yields, average fat and protein percentage, and average SCS for 3,470,474 lactations from 1,162,469 dairy cows calving in 8,566 herds spring-calving herds remained. A random subset of 500 herds was chosen for analyses; 196,775 lactation yield records from 68,323 cows remained. After all edits, the average breed composition of all animals was 90.0\% Holstein-Friesian, 3.2\% Jersey, 0.7\% Montbéliarde, 0.5\% Norwegian Red, 0.1\% Ayrshire, and 0.1\% Brown Swiss. Pedigree information for all animals was traced back to the founder animals, and founders were assigned to 1 of 11 genetic groups, based on breed; there were 208,439 animals in pedigree.

\section{Statistical Analyses}

Parity mean 305-d milk, fat, and protein yield, as well as fat and protein percentage and SCS were modeled using random regression animal models fitted across parities in ASReml (Gilmour et al., 2009). These random regression models were used to determine the parity in which a cow reached maximum milk, fat, and protein yield, highest average fat and protein percentage, and highest average SCS; they were also used to estimate the (co)variance components for each trait across parities. The random regression model fitted to all data was

$$
\begin{aligned}
& Y_{\text {ijklmnopq }}=C G_{j}+\text { Het }_{k}+\text { Rec }_{l}+\text { Age }_{m}+\sum_{n=1}^{3} b_{n} \text { Parity }^{n} \\
& +a_{i} \times \sum_{o=1}^{3} b_{o} \text { Parity }^{o}+P E_{p} \times \sum_{q=1}^{3} b_{q} \text { Parity }^{q}+e_{i j k l m n o p q}
\end{aligned}
$$

where $Y_{\text {ijklmnopq }}$ is the estimated 305-d milk, fat, or protein yield, fat or protein percentage, or SCS for cow $i$; $C G_{j}$ is the fixed effect of contemporary group $j$; $\mathrm{Het}_{k}$ is the fixed effect for heterosis class $k$ ( $k=0$ to 11$) ; R e c_{l}$ is the fixed effect for recombination loss class $l(l=0$ to $6) ; A g e_{m}$ is the fixed effect for age class relative to the parity median $m(m=1$ to 6$) ; \sum_{n=1}^{3} b_{n}$ Parity $^{n}$ is the fixed effect $n$ th-order Legendre polynomial regression on parity number; $a_{i} \times \sum_{o=1}^{3} b_{o}$ Parity $^{o}$ is the random regression coefficient on parity number for the animal additive genetic effect where $a_{i} \sim N(\mathbf{Q g}, \mathbf{A} \otimes \mathbf{G}), \mathbf{Q}$ is a matrix relating to animal with genetic groups, $\mathrm{g}$ is a vector of genetic group means, $\mathbf{A}$ is the additive animal genetic numerator relationship matrix, and $\mathbf{G}$ is the covariance matrix of the additive animal regression coefficients with order equal to the polynomial modeled. $P E_{p} \times \sum_{q=1}^{3} b_{q}$ Parity $^{q}$ is the random regression coefficient on parity number for the permanent environmental (cow) effect where $P E_{p} \sim N(0, \mathbf{I} \otimes \mathbf{C})$, I is the identity matrix and $\mathbf{C}$ is the covariance matrix of the cow random regression coefficients, and $e_{i j k l m n o p q}$ is the residual term where $e \sim N\left(0, \mathbf{I} \sigma_{e_{(\text {parity })}}^{2}\right)$ and $\sigma_{\left.e_{(\text {parity }}\right)}^{2}$ represents the residual variance and $\mathbf{I}$ the identity matrix. Residual variances were estimated separately for each parity. Residual variances were assumed homogeneous within each parity but heterogeneous between parities.

The most parsimonious order for the fixed-effect Legendre polynomial regression was determined by visually comparing the fit of a linear, quadratic, and cubic trend line to the mean lactation yield, milk composition, and SCS per parity. A cubic polynomial was the most appropriate for all traits. The most parsimonious order of the random regression was determined using the Akaike information criterion, by comparing the estimated variance components for each order, and by investigating the eigenvalues of the genetic covariance matrix.

Phenotypic Analyses. The parity and production level at which individual cows reached maximum 305d milk, fat, and protein yield as well as the highest SCS were determined using the sum of each cow's additive genetic and permanent environmental solutions from the random regression models. Linear regression models were used to estimate the relationship between first-parity yields, composition, or SCS, estimated from the animal solutions of the random regression models, and the yields, composition, or SCS in the parity of maximum yield, composition, or SCS, also estimated from the random regression model. 
Estimation of the Genetic (Co)variances and Genetic Correlations. The animal covariance functions were estimated as

$$
\delta^{2}=\boldsymbol{\Phi}^{\prime} \mathbf{K} \boldsymbol{\Phi}
$$

where $\delta^{2}$ is the animal covariance matrix for parity; $\boldsymbol{\Phi}$ is the matrix of Legendre polynomial regression coefficients, and $\mathbf{K}$ is the animal additive genetic covariance matrix estimated from the random regression model. The genetic correlations between different parities for each trait and their respective standard errors were calculated as

$$
\begin{gathered}
r_{g_{i j}}=\frac{\operatorname{covar}_{i j}}{\sqrt{\operatorname{var}_{i} \times v a r_{j}}}, \\
S E_{i j}=\frac{1-r_{g_{i j}}^{2}}{\sqrt{2}} \times \sqrt{\frac{S E_{i} \times S E_{j}}{h_{i}^{2} \times h_{j}^{2}}},
\end{gathered}
$$

where $r_{g_{i j}}$ is the genetic correlation for a trait in parities $i$ and $j$; covar $_{i j}$ is the genetic covariance between the trait in parities $i$ and $j ; v a r_{i}$ and $v a r_{j}$ are the genetic variances for the trait in parities $i$ and $j$, respectively; $S E_{i j}$ is the standard error associated with the genetic correlation of the trait between parities $i$ and $j ; h_{i}^{2}$ and $h_{j}^{2}$ are the heritability estimates for the milk trait in parity $i$ and $j$, respectively; $S E_{i}$ and $S E_{j}$ are the standard errors associated with the heritability estimates of the trait in parity $i$ and $j$, respectively. The variance of genetic change between 305-d milk, fat, and protein yield, fat, and protein percentage, and SCS in consecutive parities was estimated from the respective genetic covariance matrices as

$$
\operatorname{Var}_{c_{i j}}=\operatorname{var}_{i}+\operatorname{var}_{j}-2\left(\operatorname{covar}_{i j}\right),
$$

where $V a r_{c_{i j}}$ is the genetic variance of change between lactations $i$ and $j ; v a r_{i}$ and $v a r_{j}$ are the genetic variance associated with the trait under investigation in lactations $i$ and $j$, respectively; and covar $_{i j}$ is the estimated genetic covariance for that trait between lactations $i$ and $j$.

Animal random regression solutions from the random regression models and the matrix of Legendre polynomial regression coefficients were used to calculate an EBV per animal for each parity; only cows reaching at least fifth parity were considered further. The fixed regression solutions were used to translate the EBV to predicted performance. The lifetime production of a cow for each trait was calculated by summing the EBV for each parity, up to and including the sixth parity.

\section{RESULTS}

Summary performance statistics per parity are presented in Table 1; as $5 \%$ of records in the present study relate to cows in ninth and tenth parity, only the results relating to eighth parity and younger are presented. Of the cows retained after all edits, $81 \%$ of cows reached at least second parity and $65 \%$ of cows reached at least third parity. On average, 305-d milk, fat, and protein yield increased with increasing parity up to fifth parity. After a small reduction in the mean SCS between first and second parity, SCS consistently increased thereafter; median SCC per parity ranged from 65,000 cells/ $\mathrm{mL}$ in second parity to 122,000 cells $/ \mathrm{mL}$ in eighth parity. Mean fat and protein percentage varied by no more than 0.11 percentage units and 0.07 percentage units, respectively, between parities (Table 1).

The Akaike information criterion improved with each increasing polynomial order for the additive genetic term in the model; nonetheless, the fourth eigenvalue of cubic animal random regression explained less than $1.4 \%$ of the genetic variance for all traits. Hence, the quadratic regression was chosen as the most parsimonious for both the additive genetic and permanent environmental component for all traits.

\section{Phenotypic Analyses}

Of the cows in the present study, $91 \%$ of cows reached maximum 305-d milk yield in fifth parity (Supplementary Table S1; https://doi.org/10.6084/m9.figshare .16918429, Williams, 2021a). Of the remaining 9.0\% of cows, $5.8 \%$ reached maximum milk yield in either fourth $(3.7 \%)$ or sixth parity $(2.0 \%)$. Similarly, $98.5 \%$ and $98.6 \%$ of cows reached maximum $305-\mathrm{d}$ fat and protein yield in fourth, fifth, or sixth parity, respectively (Supplementary Table S1). Although $62.9 \%$ of cows reached their highest average protein percentage in third parity, $95.9 \%$ of cows reached their highest average fat percentage in first parity (Supplementary Table S1). In contrast to all yield and composition traits, $98.4 \%$ of cows reached their highest average SCS in eighth parity (Supplementary Table S1).

When milk, fat, and protein yield in the parity of maximum yield were regressed on their respective firstparity yields, each additional kilogram of milk, fat, and protein produced in first parity was associated with an additional $1.22,1.20$, and $1.22 \mathrm{~kg}$ of milk, fat, and protein, respectively, at maximum yield (Table 2). A 1 percentage unit increase in protein percentage in first parity was associated with a 1.1 percentage unit 


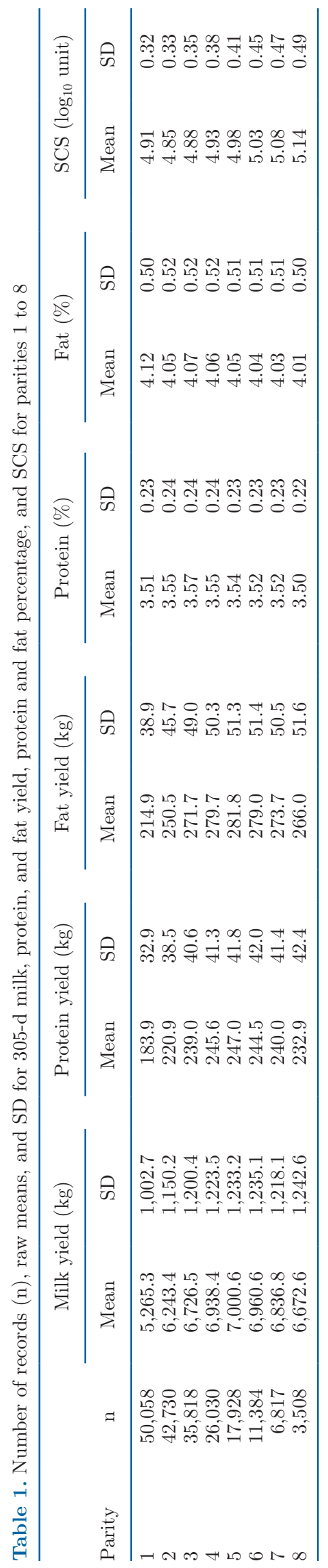

Table 2. Regression coefficient (SE in parentheses) and the root mean square error (RMSE) from the regression of milk, fat and protein yield, fat and protein percentage, and SCS in the parity of maximum production or highest average composition or SCS on their respective values in first parity; also included is the correlation between the independent and dependent variables

\begin{tabular}{lcrc}
\hline Item & $\begin{array}{c}\text { Regression } \\
\text { coefficient (SE) }\end{array}$ & \multicolumn{1}{c}{ RMSE } & Correlation \\
\hline Milk yield $(\mathrm{kg})$ & $1.219(0.0024)$ & 292.411 & 0.89 \\
Fat yield $(\mathrm{kg})$ & $1.197(0.0026)$ & 12.076 & 0.87 \\
Protein yield $(\mathrm{kg})$ & $1.219(0.0026)$ & 9.872 & 0.87 \\
Fat (\%) & $0.998(0.0001)$ & 0.012 & 1.00 \\
Protein (\%) & $1.069(0.0005)$ & 0.022 & 0.99 \\
SCS (log 10 unit) & $1.231(0.0054)$ & 0.131 & 0.66 \\
\hline
\end{tabular}

increase in protein percentage in the parity with the highest average protein percentage; the corresponding value for fat percentage was 1.0 units. A 1-unit increase in SCS in first parity was associated with a 1.2 unit increase in SCS in the parity with highest average SCS (Table 2). The correlation between maximum milk, fat, and protein yield, protein percentage, and SCS and their respective first-parity values were $0.89,0.87,0.87$, 0.99 , and 0.66 , respectively.

\section{Variance Components}

The genetic variance explained by the first eigenvalue of the fitted random regression model was $83.9 \%$, $81.4 \%, 74.8 \%, 98.5 \%, 96.4 \%$, and $87.3 \%$ for 305 -d milk, fat, and protein yield, fat and protein percentage, and SCS, respectively. Heritability estimates for 305-d milk, fat, and protein yield ranged from 0.31 (eighth parity) to 0.44 (fourth parity), from 0.28 (eighth parity) to 0.37 (fifth parity), and from 0.30 (eighth parity) to 0.37 (fourth parity), respectively (Figure 1). The heritability estimates for fat and protein percentage and SCS ranged from 0.47 (eighth parity) to 0.63 (first parity), from 0.62 (eighth parity) to 0.69 (sixth parity), and from 0.13 (second parity) to 0.23 (eighth parity), respectively (Figure 1). The genetic standard deviation for 305-d milk, fat, and protein yield was greatest in fifth parity (Figure 2). The genetic standard deviation for fat percentage, protein percentage and SCS was greatest in third, fifth, and eighth parity, respectively (Figure 2).

The variance of genetic change in milk, fat and protein yield, protein percentage, and SCS between consecutive parities reduced with increasing parity up to between fourth and fifth parity and increased with each parity thereafter for all traits, whereas the variance of genetic change in fat percentage reduced with increasing parity up to between fifth and sixth parity (Figure 3 ). The variance of genetic change between parities was greatest between the first and second parity for 


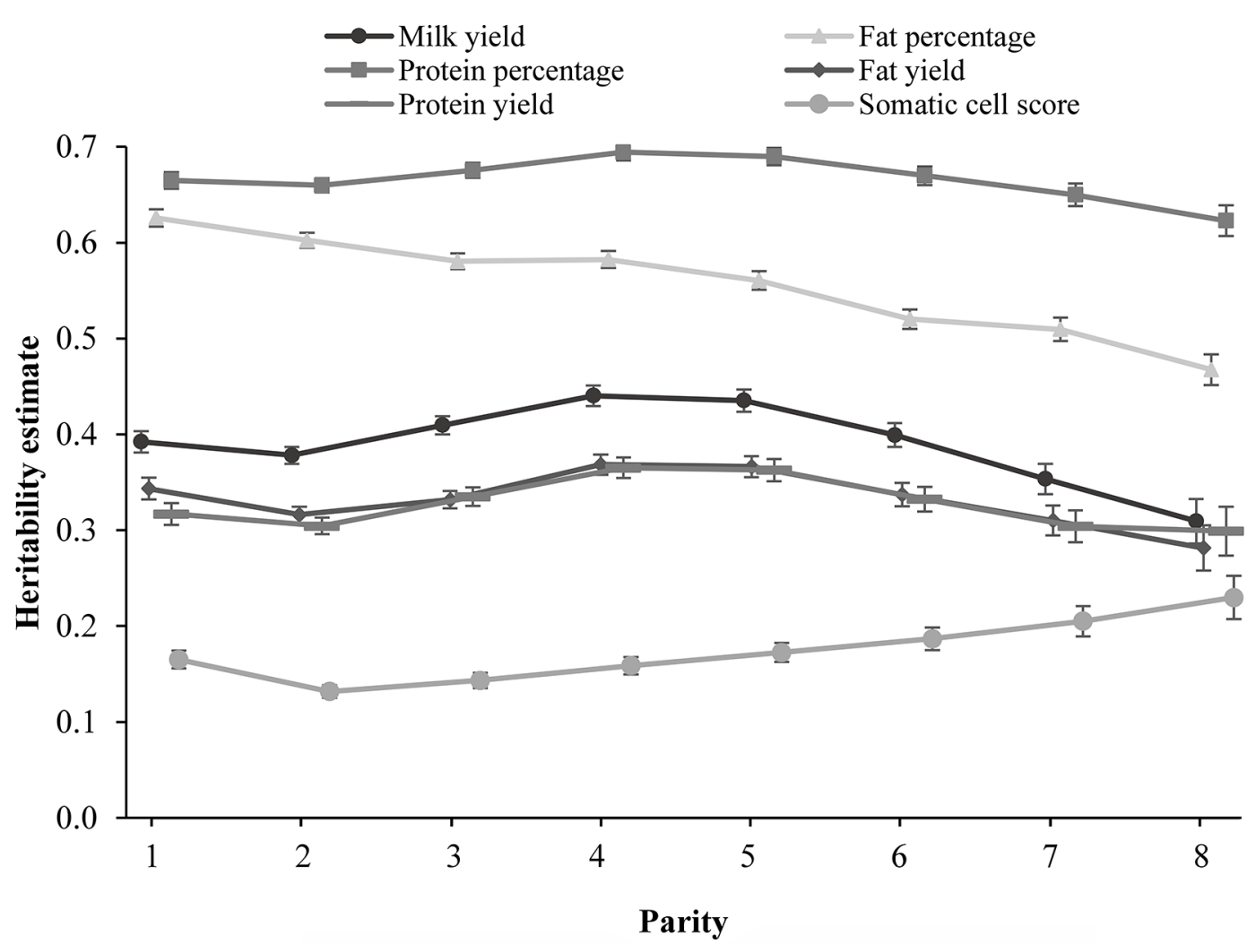

Figure 1. Heritability estimates for 305-d milk yield (kg), fat percentage (\%), protein percentage (\%), SCS (log 10 unit), 305-d fat yield (kg), and 305-d protein yield (kg). Standard error bars represent $1 \mathrm{SE}$ above and below the heritability estimate.

all traits. Pairwise genetic correlations between 305-d milk yield among the different parities varied from 0.67 to 1.00 (Table 3), the strength of the genetic correlations being inversely related to the interval between the compared parities; this trend of weakening correlations as the parities compared diverged was also true for fat and protein percentage (Table 4), SCS (Table 3), and 305-d fat and protein yield (Supplementary Table S2; https://doi.org/10.6084/m9.figshare.16918498.v2, Williams, 2021b).

Eigenfunctions. The sign of the eigenfunction of the genetic covariance matrix associated with the largest eigenvalue (i.e., the intercept term) did not change across parities for any of the traits investigated (Figure 4). The eigenfunction associated with the second eigenvalue accounting for $13 \%, 15 \%$, and $23 \%$ of the genetic variance for 305-d milk, fat, and protein yield was moderately curvilinear, with the sign changing in the second and again in the seventh parity for milk and fat yield, whereas the sign changed only once, in seventh parity, for protein yield (Figure 4). The second eigenvalue accounted for $1.0 \%$ and $2.7 \%$ of the genetic variance in fat percentage and protein percentage (Figure 4); whereas the sign of the second eigenfunction changed once for fat percentage in seventh parity, the sign of the second eigenfunction changed twice for protein percentage (i.e., in second parity and again in eighth parity). The second eigenvalue accounted for $9.1 \%$ of the genetic variance in SCS and the sign of the associated eigenfunction changed in eighth parity for SCS (Figure 4).

Estimated Breeding Values. Differences existed between cows in the height and shape of the EBV profiles across parities for all traits investigated (Figure 5). Differences in the shape of the EBV profiles per cow for milk, fat, and protein yield were minimal prior to third parity; after third parity, the steepness of the decline or incline in EBV for the yield traits varied greatly among individual cows (Figure 5). The shape of the EBV profile for SCS and the steepness of the decline or incline in EBV for the SCS varied greatly among individual cows.

The lifetime yield of a cow for each trait was calculated by summing the yield EBV for each parity up to and including the sixth parity. To determine if differences in the trajectory of each trait across parities exist between cows with similar expected lifetime yield, the 11 cows with expected lifetime yield closest to the median lifetime yield for each trait were compared. The shape of the EBV profiles was generally consistent between cows 
up to fifth parity for all traits with differences among cows evident thereafter (Figure 6).

\section{DISCUSSION}

Low milk yield and high SCS are frequently reported as primary reasons for dairy cow culling (Pinedo et al., 2010; Kerslake et al., 2018; De Vries and Marcondes, 2020). Identifying and selecting cows that maintain their maximum milk production as they age or cows that maintain low SCS with age could therefore reduce the pressure to cull prematurely, thus improving dairy cow longevity. Achieving these improvements in dairy cow longevity will result in a higher proportion of cows surviving to older parities (>sixth parity); hence, understanding the dynamics and trajectories of milk yield and SCS will become more important. Although previous studies have investigated the trajectory and persistency of yield within a lactation (Jakobsen et al., 2002; Togashi et al., 2008; Cole and Null, 2009), no study has yet specifically investigated the dynamics of milk production or SCS across parities. The objective of the present study was thus to understand the phenotypic and genetic dynamics of lactation yields and SCS across parities in dairy cows and, by doing so, quantify the potential to alter the trajectory through breeding.

Heifer rearing is a substantial cost to dairy producers representing 15 to $20 \%$ of total production costs on a dairy farm (Heinrichs, 1993). It has been estimated that the heifer rearing cost is not repaid until the heifer completes 1.63 lactations, although this is a function of milk price and input costs (Berry et al., 2015). Hence, extending cow productive life can have a favorable impact on reducing farm costs through a lesser requirement for replacement heifers. A more mature cow herd can also improve herd revenue; more mature cows yield more milk per lactation (Berry and
Ring, 2020) and produce heavier male calves for sale (Dunne et al., 2021). Traditionally high replacement rate was a prerequisite for achieving rapid genetic gain. This no longer needs to necessarily be true in light of the advancements in both genomic evaluations and reproductive technologies as well as improvements in dairy cow reproductive performance (Berry et al., 2014; García-Ruiz et al., 2016). If cow longevity increases, owing to improvements in female reproductive performance, then proportionally fewer replacements are actually needed in the first place. Next, with sexed semen (assuming good conception rates) and low heifer mortality, most, if not all, replacements could actually be generated just from maiden heifers. These heifers should not only be the genetically most elite in the herd but also the most fertile; if genomically tested, then the accuracy of their genetic evaluations would not be that much inferior to their mature counterparts. Hence, with good cow longevity, genetic gain in a herd could actually be accelerated; whether this materializes can be deterministically quantified based on the damto-dam selection pathway outlined by Robertson and Rendel (1950) populated with respective statistics (i.e., selection intensity, accuracy of selection, and generation interval). Having said this, replacement rate is a function of both involuntary (e.g., reproductive failure) and voluntary (e.g., low milk yield, high SCC) culling, and therefore, the latter needs to be afforded the same research effort as has been expended on improving (genetic merit for) dairy cow reproductive performance in the past few decades.

\section{Improving Longevity Through Maintaining High Milk Production}

The mean milk, fat, and protein yield, as well as the fat and protein percentage per parity reported in the
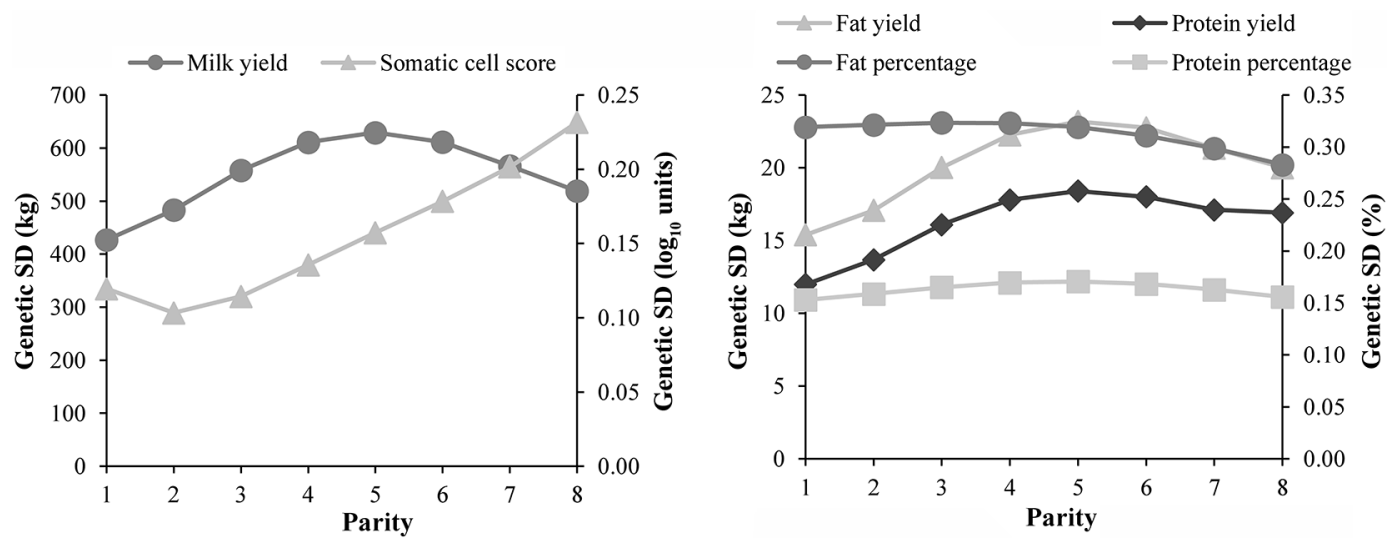

Figure 2. Additive genetic standard deviation estimates for 305-d (a) milk yield (kg; primary axis), SCS ( $\log _{10}$ units; secondary axis), and (b) fat yield (kg; primary axis), protein yield (kg; primary axis), fat percentage (\%; secondary axis), and protein percentage (\%; secondary axis). 

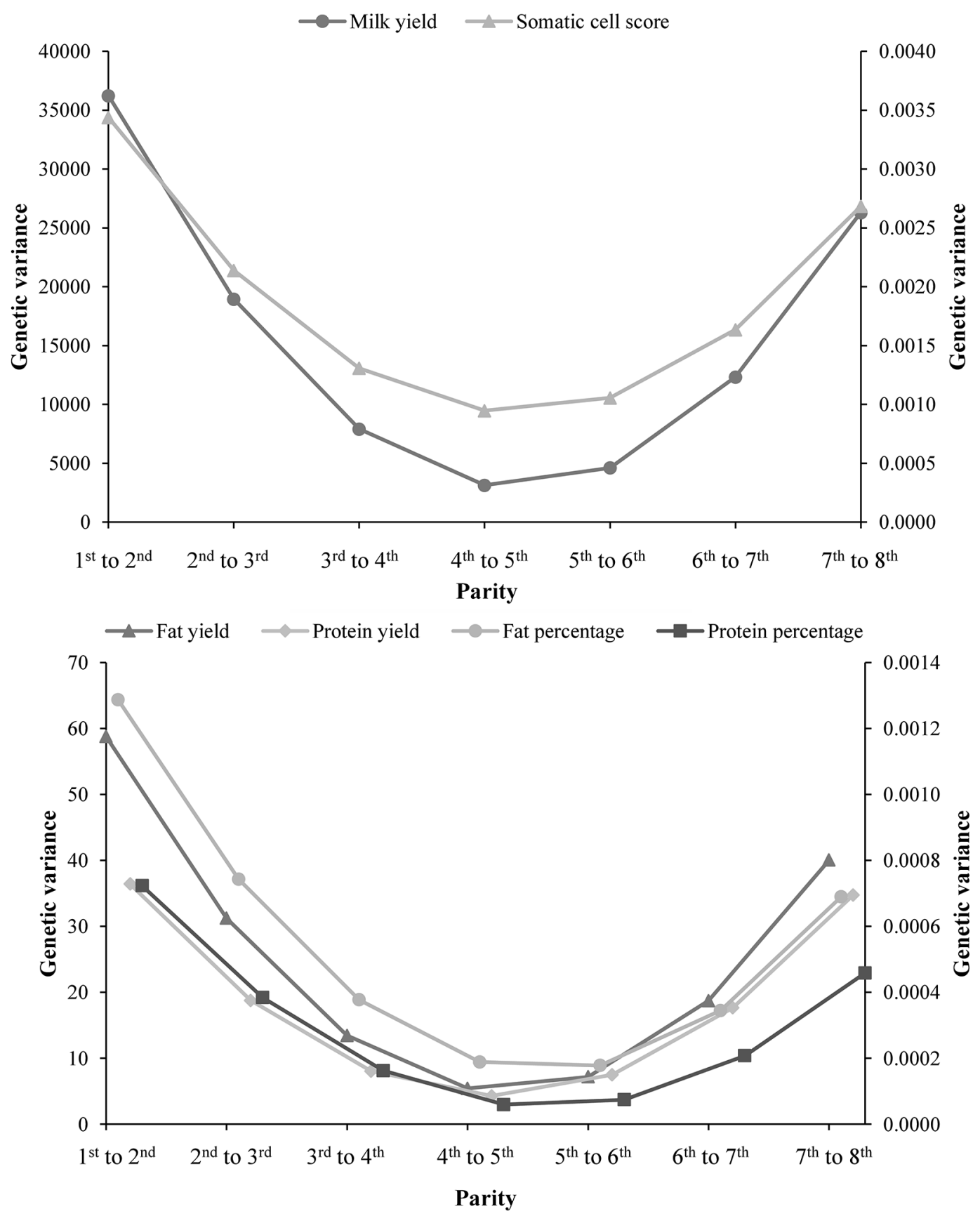

Figure 3. The variance of genetic change between parities for (a) 305-d milk yield ( $\mathrm{kg}^{2}$; primary axis) and SCS ( $\log _{10}$ unit ${ }^{2}$; secondary axis) and (b) 305-d fat yield $\left(\mathrm{kg}^{2}\right.$; primary axis), 305-d protein yield ( $\mathrm{kg}^{2}$; primary axis), fat percentage $\left(\%{ }^{2}\right.$; secondary axis), and protein percentage $\left(\%^{2}\right.$; secondary axis).

present study were similar to average yields reported elsewhere for Irish pasture-based dairy cows (Cobuci et al., 2011; Coffey et al., 2016; O'Sullivan et al., 2019). No previous studies have investigated whether interanimal variation exists for the parity in which maximum milk yield or highest average composition is achieved. Whereas the majority of cows in the present study reached their maximum milk, fat, and protein yield in fifth parity, consistent with the mean parity yields previously reported for dairy cows (Guo et al., 2002; Yang et al., 2005; Lee and Kim, 2006; Torshizi et al., 2017), between $7 \%$ and $17 \%$ of cows reached their maximum yields in other parities. The proportion of cows that reached their maximum yields in parities other than 
Table 3. Genetic correlations (SE in parentheses) between 305-d milk yield $(\mathrm{kg})$ in different parities (above diagonal) and SCS (log 10 units) in different parities (below diagonal)

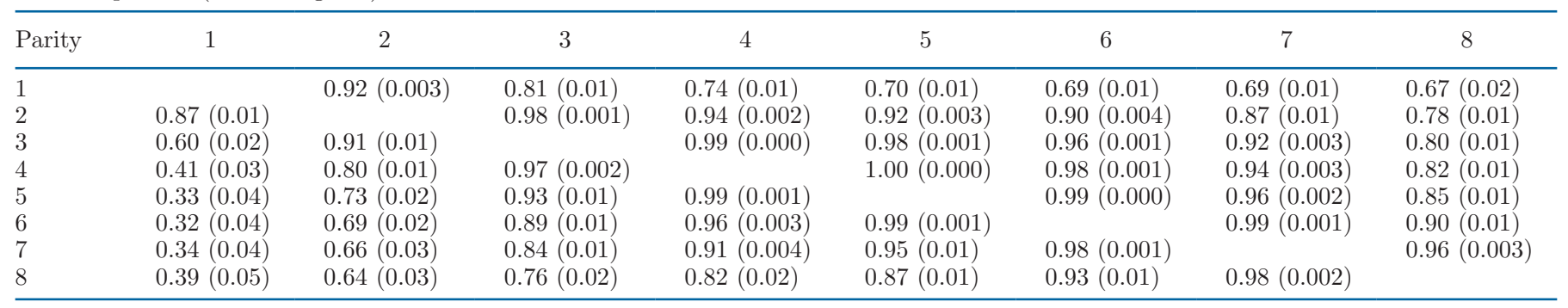

fifth parity highlights the extent of the interanimal variation that currently exists for the parity in which individual cows reach maximum yield.

The heritability estimates of milk, fat, and protein yields in each parity were similar to those previously reported for individual parities in Swedish Holstein cows (Carlén et al., 2004) and Uruguayan dairy cows (Frioni et al., 2017), and across parities in Irish dairy cows (Cromie et al., 1998; McParland et al., 2015). In the present study, the eigenfunctions (continuous functions formed by decomposing variance or covariance matrices; Kirkpatrick and Heckman, 1989) provided information on how milk production and SCS trajectories across parities could change in response to selection. Such eigenfunctions for milk yield, composition, and SCS across lactations have not been previously reported, although eigenvalues and eigenfunctions of lactation yields within individual parities have been investigated previously (Togashi et al., 2008). The majority of the genetic variance in milk, fat, and protein yield across parities in the present study was attributable to the model intercept terms, suggesting that the greatest opportunity exists to alter the height of the profiles, which could increase yields in all parities equally. The strong genetic correlations observed between milk, fat, and protein yield in consecutive parities substantiate the high proportion of the genetic variance of all yield traits explained by the model intercept term. These strong genetic correlations are consistent with the moderate repeatability of yield traits across parities in dairy cows (Berry and McCarthy, 2012; Visentin et al., 2017; Costa et al., 2019). Additionally, the inverse relationship between the strength of the genetic correlations and the interval between parities compared agrees with previous studies using random regression models on milk yield (Zarnecki et al., 1991; Carlén et al., 2004; Frioni et al., 2017). The sometimes moderate genetic correlations between the same trait in different parities imply that the appropriate statistical modeling is necessary to generate accurate genetic evaluations, especially when older parity data are included in the evaluation.

Nevertheless, the EBV profiles of cows highlight the extent of interanimal differences that exist for the rate of decline in genetic merit for milk yield and composition after maximum yield and highest average composition has been reached. Although it was necessary for cows to have achieved $\geq 5$ lactations to identify these differences, it may be possible to estimate breeding values for milk yields for cows in earlier parities without the need for phenotypic records. Such estimated breeding values could enable producers to make breeding decisions for young cows based on predicted yields, therefore retaining genetically superior cows without slowing down genetic improvement. Given the sign of both the second and third eigenfunctions for all yield (and composition) traits changed across parities, there is potential to alter the shape of the yield profile, and therefore the persistency of yield with advancing parity number. If selection pressure was exerted on the second

Table 4. Genetic correlations (SE in parentheses) between 305-d fat percentage in different parities (above diagonal) and 305-d protein percentage in different parities (below diagonal)

\begin{tabular}{|c|c|c|c|c|c|c|c|c|}
\hline Parity & 1 & 2 & 3 & 4 & 5 & 6 & 7 & 8 \\
\hline 2 & $0.99(0.000)$ & & $1.00(0.000)$ & $0.99(0.000)$ & $0.98(0.000)$ & $0.98(0.000)$ & $0.98(0.001)$ & $0.98(0.001)$ \\
\hline 3 & $0.96(0.001)$ & $0.99(0.000)$ & & $1.00(0.000)$ & $1.00(0.000)$ & $0.99(0.000)$ & $0.99(0.000)$ & $0.98(0.000)$ \\
\hline 5 & $0.93(0.001)$ & $0.98(0.000)$ & $0.99(0.000)$ & $1.00(0.000)$ & & $1.00(0.000)$ & $1.00(0.000)$ & $0.99(0.000)$ \\
\hline 6 & $0.93(0.001)$ & $0.97(0.000)$ & $0.99(0.000)$ & $1.00(0.000)$ & $1.00(0.000)$ & & $1.00(0.000)$ & $0.99(0.000)$ \\
\hline 7 & $0.93(0.001)$ & $0.97(0.001)$ & $0.98(0.000)$ & $0.99(0.000)$ & $0.99(0.000)$ & $1.00(0.000)$ & & \\
\hline
\end{tabular}


eigenfunctions for any of the yield traits, the persistency of production could be improved by increasing production in parities typically associated with lower yields and decreasing production in other parities. Togashi and Lin (2006) also suggested persistency of milk production, albeit within lactation, could be improved by exerting selection pressure on the second eigenfunction of milk production. Nonetheless, in the present study, the genetic variation associated with the second eigenfunction of milk, fat, and protein yield accounted for just $13 \%, 15 \%$, and $23 \%$ of the genetic variance, respectively. Therefore, in order to alter the shape of the milk, fat, and protein yield profiles a greater weight would need to be imposed on the second eigenfunctions.
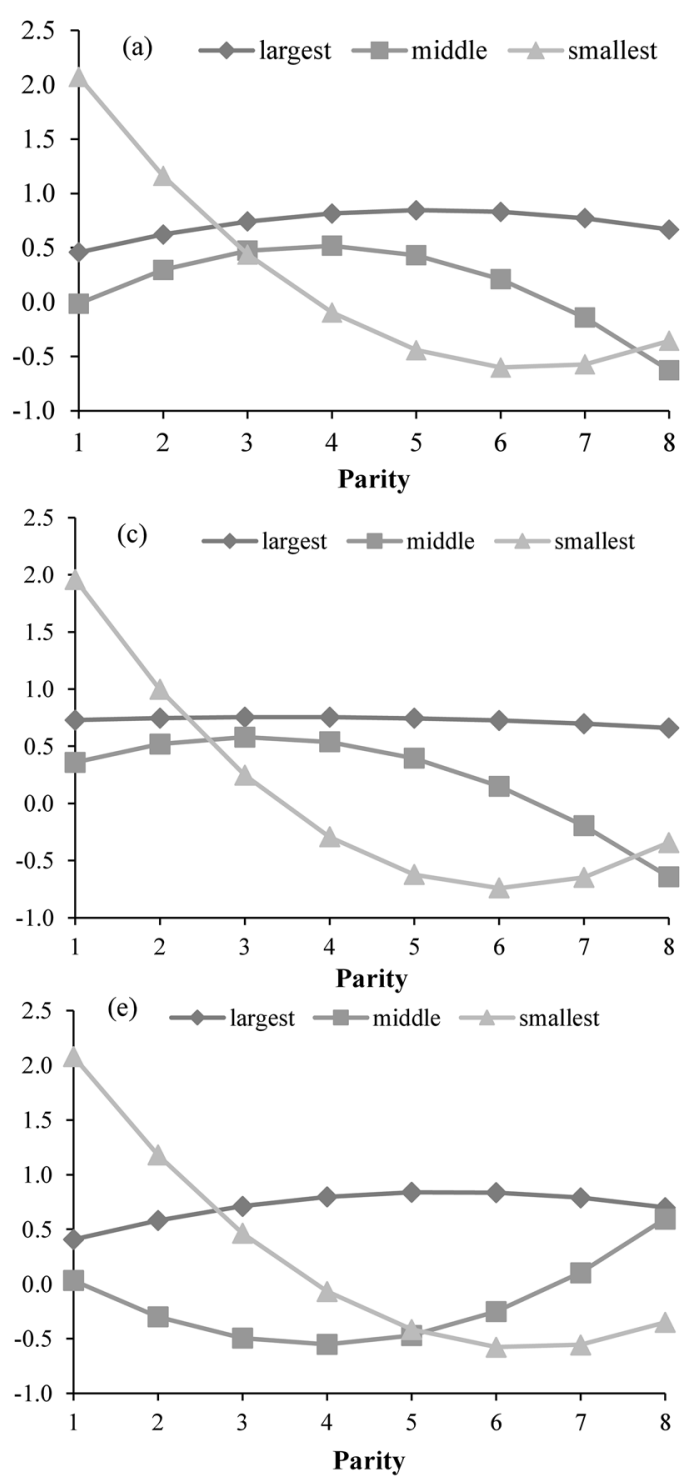

\section{Improving Longevity Through Retaining Low SCS in Older Cows}

Mastitis is the most frequent and costly disease affecting dairy cows globally (Caraviello et al., 2005; Abebe et al., 2016) with the genetic correlations between clinical mastitis and SCS ranging from 0.37 to 0.70 (Pösö and Mäntysaari, 1996; Kadarmideen and Pryce, 2001); the large range in the genetic correlations between clinical mastitis and SCS may be a result of differences in the accuracy of the diagnosis of the mastitis phenotype. It is not surprising then that both mastitis and high SCS are frequently cited as independent reasons for dairy cow culling (Pinedo et al., 2010; Kerslake et al.,
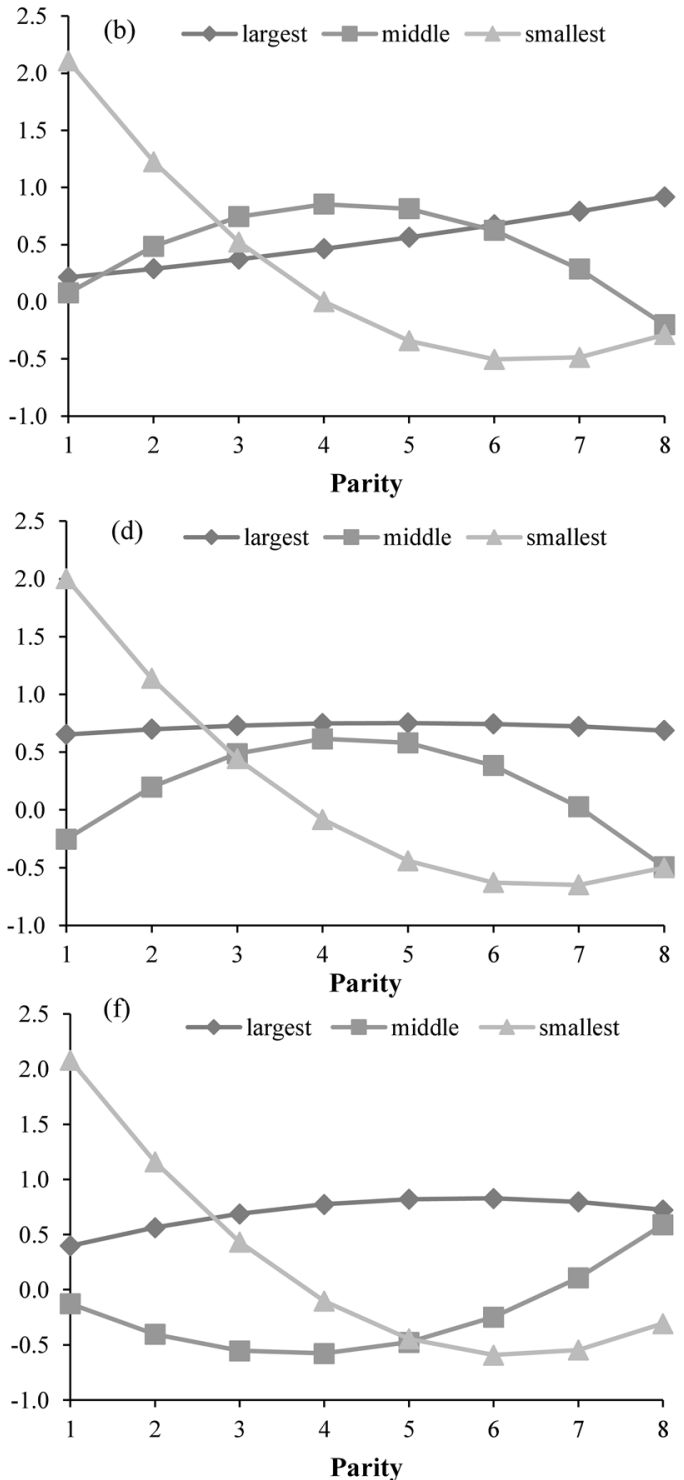

Figure 4. Eigenfunctions associated with the largest, middle, and smallest eigenvalues for (a) 305-d milk yield, (b) SCS, (c) fat percentage, (d) protein percentage, (e) 305-d fat yield, and (f) 305-d protein yield. 
2018; De Vries and Marcondes, 2020); the contribution to culling policies is expected to grow in the future given the pressures being imposed on the more prudent use of antimicrobials in dairy cow production system (Crispie et al., 2004). The risk of culling due to high SCS or mastitis is reported to increase as dairy cows age (Pinedo et al., 2010; Kerslake et al., 2018), with the risk of culling due to high SCS or mastitis doubling between first and fifth parity (Kerslake et al., 2018). This increased risk of culling corresponds with a trend of increased SCS with each progressing parity reported in the present study and previously reported trends of increased SCS and rate of clinical mastitis in aging cows (Berry et al., 2007; Walsh et al., 2007).
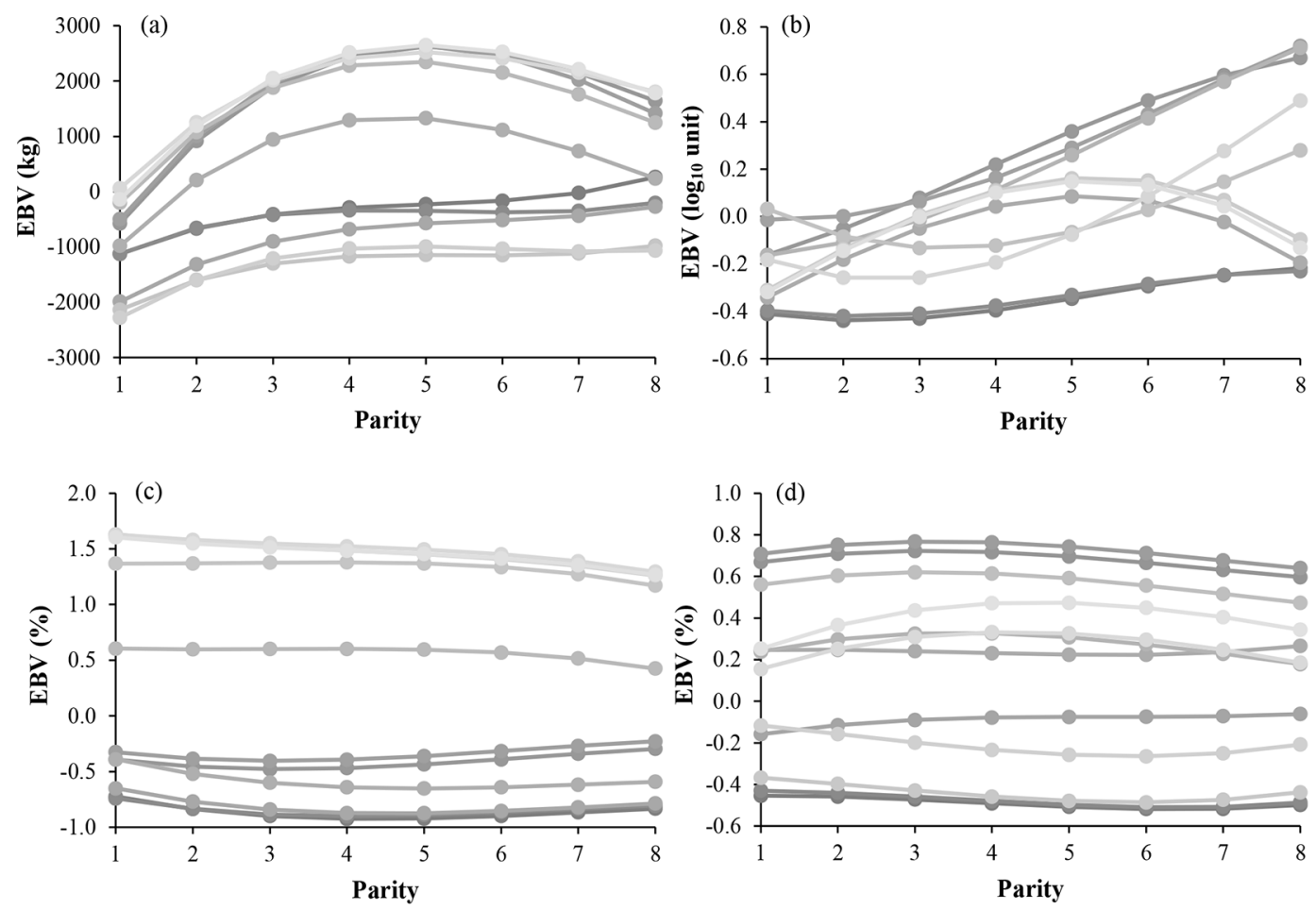

The heritability of SCS in younger parities ( $\leq$ seventh parity) were similar to those reported for individual parities in Swedish Holstein cows (Carlén et al., 2004) and across parities in both Irish (Berry and McCarthy, 2012) and Italian dairy cows (Costa et al., 2019). The increased heritability of SCS in older parities has not been reported previously in dairy cows, as no study has reported the heritability of SCS in individual parities above parity 3. Furthermore, the eigenfunctions associated with the additive genetic covariance matrix of SCS across parities have not previously been reported. Similar to all milk yield and composition traits, the majority of the genetic variance of SCS $(87 \%)$ was attributable to the model intercept term suggesting the
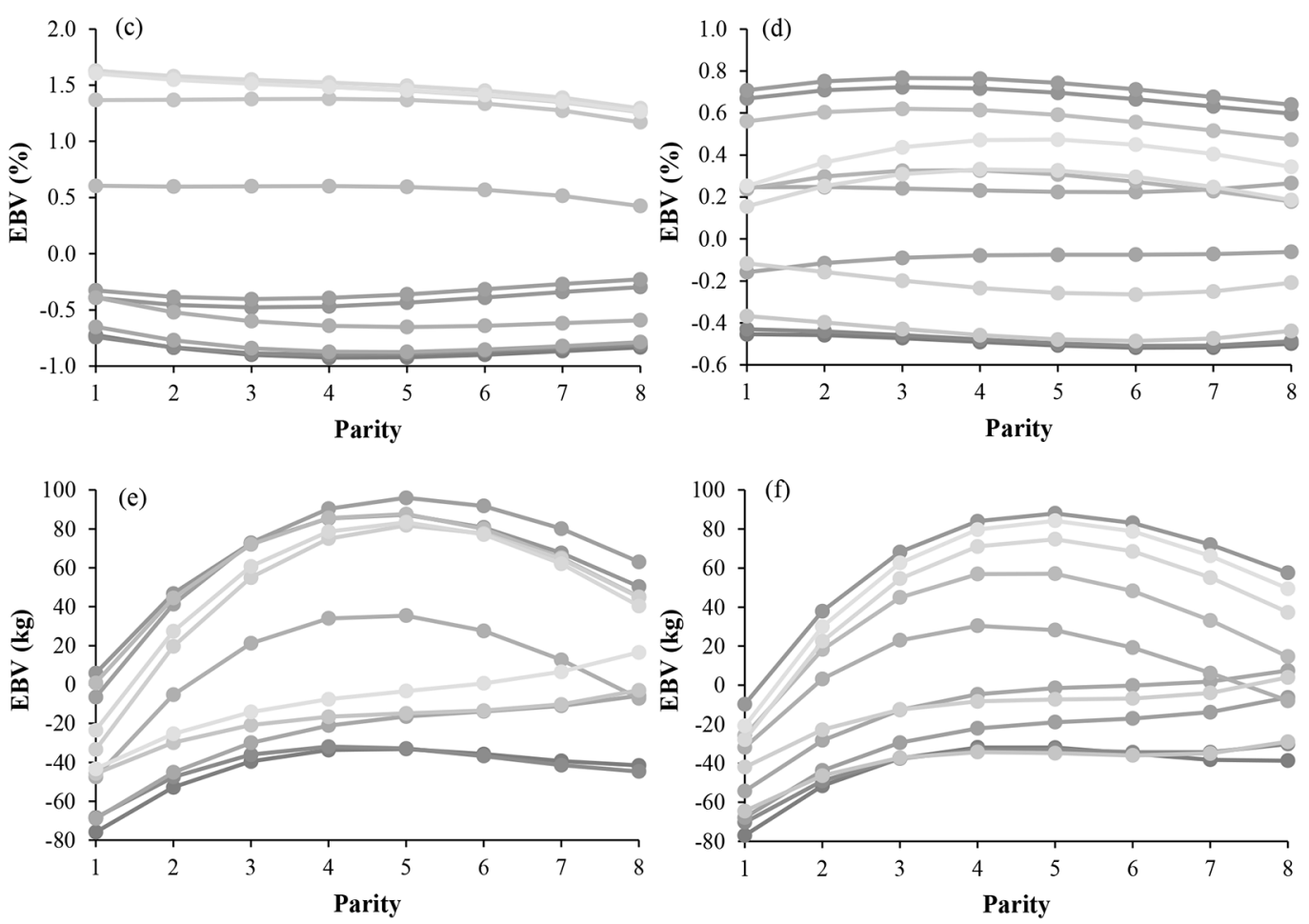

Figure 5. Estimated breeding values for cows with the most extreme (diverse) EBV, when compared with all cows reaching $\geq$ fifth parity, for each parity for (a) 305-d milk yield, (b) SCS, (c) fat percentage, (d) protein percentage, (e) 305-d fat yield, and (f) 305-d protein yield. 

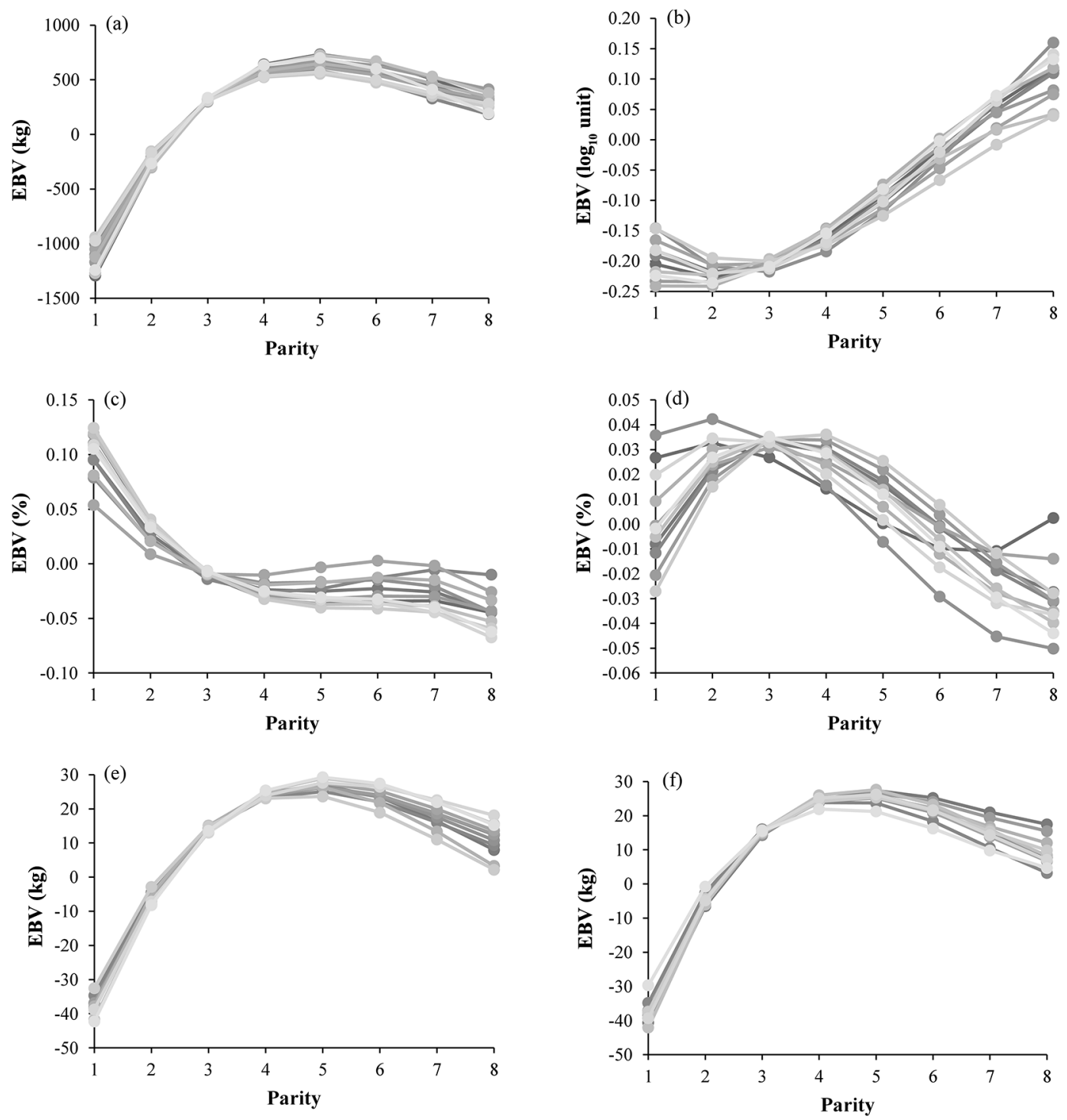

Figure 6. Estimated breeding values for cows with median lifetime production values when compared with all cows reaching $\geq$ fifth parity, in each parity for (a) 305-d milk yield, (b) SCS, (c) fat percentage, (d) protein percentage, (e) 305-d fat yield, and (f) 305-d protein yield.

greatest opportunity exists to alter (i.e., lower) the overall height of the SCS profile. The strong genetic correlations between SCS in consecutive parities substantiate the high proportion of the genetic variance of SCS explained by the model intercept term and are in agreement with the moderate repeatability of SCS between parities (0.33 to 0.53; Berry and McCarthy, 2012; Costa et al., 2019). The inverse relationship between the strength of the genetic correlations and the interval between parities compared is also in agreement with Carlén et al. (2004), who used random regression models on SCS, albeit limited to Swedish Holstein cows in first to third parity.

As the risk of culling due to high SCS increases with age, the identification of cows with a genetic predisposi- tion for higher SCS in later lactations could be useful for enacting bespoke management strategies, such as targeted dry cow therapy for cows with a known predisposition for high SCS. Such cows, with a genetic predisposition for higher SCS as they age, could be identified from their EBV profiles for SCS. Alternatively, dairy cow longevity could be improved by maintaining low SCS in older cows, which could be achieved by selecting cows that have a genetic predisposition to maintain low SCS even in older parities or by altering the height and shape of SCS profile; the advantage of this strategy rather than selection directly on cow longevity is the greater heritability of SCS implying a more accurate genetic evaluation for individual cows. The change in the sign of both the second and third eigenfunctions for 
SCS provides evidence that there is indeed potential to alter the shape of the SCS profile. If selection pressure was exerted on the third eigenfunction for SCS, SCS could be decreased between fifth and eighth parity; selecting for SCS using this eigenfunction could increase dairy cow longevity by reducing SCS in all older cows (up to eighth parity) when the risk of culling due to high SCS is increased. Nevertheless, given that the genetic variation associated with the third eigenfunction for SCS was limited (4\%), in order to alter the shape of the SCS through selection, a greater weight would have to be imposed on this eigenfunction.

\section{CONCLUSIONS}

By estimating the trajectories of genetic merit for daughter milk yield and SCS of individual cows, the present study highlighted the extent of interanimal variability that currently exists for the height and shape of the EBV profiles across parities. These EBV profiles of individual cows have the potential to assist dairy producers with management decisions, such as culling based on expected trajectory of future milk yields (Kelleher et al., 2015) or selective dry cow therapy for cows expected to have high SCS in the future. Additionally, the eigenfunctions of the covariance matrices of milk yield and SCS presented provide a strategy on how the trajectory of both milk yield and SCS could be altered to improve dairy cow longevity by reducing the requirement for culling due to low milk yield and high SCS, particularly in older parities.

\section{ACKNOWLEDGMENTS}

This publication has emanated from research supported in part by the Department of Agriculture, Food and the Marine (Dublin, Ireland) Research Stimulus Fund 17/S/235 (GreenBreed, Dublin, Ireland) as well as funding from a research grant from Science Foundation Ireland and the Department of Agriculture, Food and Marine on behalf of the Government of Ireland under the grant 16/RC/3835 (VistaMilk, Dublin, Ireland). The authors have not stated any conflicts of interest.

\section{REFERENCES}

Abebe, R., H. Hatiya, M. Abera, B. Megersa, and K. Asmare. 2016. Bovine mastitis: Prevalence, risk factors and isolation of Staphylococcus aureus in dairy herds at Hawassa milk shed, South Ethiopia. BMC Vet. Res. 12:270. https://doi.org/10.1186/s12917-016 $-0905-3$.

Adamczyk, K., D. Zaborski, W. Grzesiak, J. Makulska, and W. Jagusiak. 2016. Recognition of culling reasons in Polish dairy cows using data mining methods. Comput. Electron. Agric. 127:26-37. https://doi.org/10.1016/j.compag.2016.05.011.
Animal Health Ireland. 2020. What is AMR? Accessed Oct. 21, 2021. https://animalhealthireland.ie/assets/uploads/2021/06/AHI -Bulletin-August-2020-Revised-2021.pdf.

Berry, D. P., F. Buckley, and S. T. Butler. 2015. Reducing replacement cost on Irish dairy farms. Pages 23-30 in Moorepark ' 15 Irish dairying sustainable expansion. Accessed Sep. 10, 2021. https:// www.teagasc.ie/media/website/publications/2015/Irish_Dairying -Sustainable_Expansion_Moorepark15.pdf.

Berry, D. P., B. L. Harris, A. M. Winkelman, and W. Montgomerie. 2005. Phenotypic associations between traits other than production and longevity in New Zealand dairy cattle with special emphasis on management traits. Interbull Bull. 33:59-62.

Berry, D. P., J. F. Kearney, K. Twomey, and R. D. Evans. 2013. Genetics of reproductive performance in seasonal calving dairy cattle production systems. Ir. J. Agric. Food Res. 52:1-16.

Berry, D. P., J. M. Lee, K. A. Macdonald, K. Stafford, L. Matthews, and J. R. Roche. 2007. Associations among body condition score, body weight, somatic cell count, and clinical mastitis in seasonally calving dairy cattle. J. Dairy Sci. 90:637-648. https://doi.org/10 .3168/jds.S0022-0302(07)71546-1.

Berry, D. P., and J. McCarthy. 2012. Genetic and non-genetic factors associated with milking order in lactating dairy cows. Appl Anim. Behav. Sci. 136:15-19. https://doi.org/10.1016/j.applanim .2011.11.012.

Berry, D. P., and S. C. Ring. 2020. The beef merit of the sire mated to a dairy female affects her subsequent performance. J. Dairy Sci. 103:8241-8250. https://doi.org/10.3168/jds.2020-18521.

Berry, D. P., E. Wall, and J. E. Pryce. 2014. Genetics and genomics of reproductive performance in dairy and beef cattle. Animal 8:105-121. https://doi.org/10.1017/S1751731114000743.

Caraviello, D. Z., K. A. Weigel, G. E. Shook, and P. L. Ruegg. 2005. Assessment of the impact of somatic cell count on functional longevity in Holstein and Jersey cattle using survival analysis methodology. J. Dairy Sci. 88:804-811. https://doi.org/10.3168/jds .S0022-0302(05)72745-4.

Carlén, E., E. Strandberg, and A. Roth. 2004. Genetic parameters for clinical mastitis, somatic cell score, and production in the first three lactations of Swedish Holstein cows. J. Dairy Sci. 87:30623070. https://doi.org/10.3168/jds.S0022-0302(04)73439-6.

Cobuci, J. A., C. N. Costa, J. Braccini Neto, and A. F. D. Freitas. 2011. Genetic parameters for milk production by using random regression models with different alternatives of fixed regression modeling. Rev. Bras. Zootec. 40:557-567. https://doi.org/10.1590/ S1516-35982011000300013.

Coffey, E. L., B. Horan, R. D. Evans, and D. P. Berry. 2016. Milk production and fertility performance of Holstein, Friesian, and Jersey purebred cows and their respective crosses in seasonal-calving commercial farms. J. Dairy Sci. 99:5681-5689. https://doi.org/10 $.3168 /$ jds.2015-10530.

Cole, J. B., and D. J. Null. 2009. Genetic evaluation of lactation persistency for five breeds of dairy cattle. J. Dairy Sci. 92:2248-2258. https://doi.org/10.3168/jds.2008-1825.

Cole, J. B., and P. M. VanRaden. 2018. Symposium review: Possibilities in an age of genomics: The future of selection indices. J. Dairy Sci. 101:3686-3701. https://doi.org/10.3168/jds.2017-13335.

Costa, A., N. Lopez-Villalobos, G. Visentin, M. De Marchi, M. Cassandro, and M. Penasa. 2019. Heritability and repeatability of milk lactose and its relationships with traditional milk traits, somatic cell score and freezing point in Holstein cows. Animal 13:909-916. https://doi.org/10.1017/S1751731118002094.

Crispie, F., J. Flynn, R. P. Ross, C. Hill, and W. J. Meaney. 2004 Dry cow therapy with a non-antibiotic intramammary teat seal-A review. Ir. Vet. J. 57:412-418. https://doi.org/10.1186/2046-0481 $-57-7-412$

Cromie, A. R., D. L. Kelleher, F. J. Gordon, and M. Rath. 1998. Genotype by environment interaction for milk production traits in Holstein Friesian dairy cattle in Ireland. Interbull Bull. 17:100-104.

De Vries, A. 2020. Symposium review: Why revisit dairy cattle productive lifespan? J. Dairy Sci. 103:3838-3845. https://doi.org/10 .3168/jds.2019-17361. 
De Vries, A., and M. I. Marcondes. 2020. Overview of factors affecting productive lifespan of dairy cows. Animal 14:s155-s164. https:// doi.org/10.1017/S1751731119003264.

Dunne, F. L., M. M. Kelleher, B. Horan, R. D. Evans, and D. P. Berry. 2021. Predicting male dairy calf live weight for use in calf management decision support. JDS Commun. 2:257-261. https://doi.org/ 10.3168/jdsc.2021-0078.

Frioni, N., G. Rovere, I. Aguilar, and J. I. Urioste. 2017. Genetic parameters and correlations between days open and production traits across lactations in pasture based dairy production systems. Livest. Sci. 204:104-109. https://doi.org/10.1016/j.livsci.2017.08.018.

García-Ruiz, A., J. B. Cole, P. M. VanRaden, G. R. Wiggans, F. J. Ruiz-López, and C. P. Van Tassell. 2016. Changes in genetic selection differentials and generation intervals in US Holstein dairy cattle as a result of genomic selection. Proc. Natl. Acad. Sci. USA 113:E3995-E4004. https://doi.org/10.1073/pnas.1519061113.

Gilmour, A. R., B. J. Gogel, B. R. Cuillis, and R. Thompson. 2009. ASReml user guide release 3.0. VSN International Ltd.

Guo, Z., M. S. Lund, M. P. Madsen, I. Korsgaard, and J. Jensen. 2002. Genetic parameter estimation for milk yield over multiple parities and various lengths of lactation in Danish Jerseys by random regression models. J. Dairy Sci. 85:1596-1606. https://doi.org/10 $.3168 /$ jds.S0022-0302(02)74230-6.

Heinrichs, A. J. 1993. Raising dairy replacements to meet the needs of the 21st century. J. Dairy Sci. 76:3179-3187. https://doi.org/10 .3168/jds.S0022-0302(93)77656-0.

Jakobsen, J. H., P. Madsen, J. Jensen, J. Pedersen, L. G. Christensen, and D. A. Sorensen. 2002. Genetic parameters for milk production and persistency for Danish Holsteins estimated in random regression models using REML. J. Dairy Sci. 85:1607-1616. https://doi .org/10.3168/jds.S0022-0302(02)74231-8.

Kadarmideen, H. N., and J. E. Pryce. 2001. Genetic and economic relationships between somatic cell count and clinical mastitis and their use in selection for mastitis resistance in dairy cattle. Anim. Sci. 73:19-28. https://doi.org/10.1017/S135772980005801X.

Kelleher, M. M., P. R. Amer, L. Shalloo, R. D. Evans, T. J. Byrne, F. Buckley, and D. P. Berry. 2015. Development of an index to rank dairy females on expected lifetime profit. J. Dairy Sci. 98:42254239. https://doi.org/10.3168/jds.2014-9073.

Kerslake, J. I., P. R. Amer, P. L. O'Neill, S. L. Wong, J. R. Roche, and C. V. C. Phyn. 2018. Economic costs of recorded reasons for cow mortality and culling in a pasture-based dairy industry. J. Dairy Sci. 101:1795-1803. https://doi.org/10.3168/jds.2017-13124.

Kirkpatrick, M., and N. Heckman. 1989. A quantitative genetic model for growth, shape, reaction norms, and other infinite-dimensional characters. J. Math. Biol. 27:429-450. https://doi.org/10.1007/ BF00290638.

Lee, J. Y., and I. H. Kim. 2006. Advancing parity is associated with high milk production at the cost of body condition and increased periparturient disorders in dairy herds. J. Vet. Sci. 7:161-166. https://doi.org/10.4142/jvs.2006.7.2.161.

McParland, S., E. Kennedy, E. Lewis, S. G. Moore, B. McCarthy, M. O'Donovan, and D. P. Berry. 2015. Genetic parameters of dairy cow energy intake and body energy status predicted using midinfrared spectrometry of milk. J. Dairy Sci. 98:1310-1320. https:/ /doi.org/10.3168/jds.2014-8892.

O'Sullivan, M., B. Horan, K. M. Pierce, S. McParland, K. O'Sullivan, and F. Buckley. 2019. Milk production of Holstein-Friesian cows of divergent Economic Breeding Index evaluated under seasonal pasture-based management. J. Dairy Sci. 102:2560-2577. https:// doi.org/10.3168/jds.2018-15559.

Olori, V. E., and P. J. B. Galesloot. 1999. Projection of partial lactation records and calculation of 305-day yields in the Republic of Ireland. Interbull Bull. 22:149-154.
Pinedo, P. J., A. De Vries, and D. W. Webb. 2010. Dynamics of culling risk with disposal codes reported by Dairy Herd Improvement dairy herds. J. Dairy Sci. 93:2250-2261. https://doi.org/10.3168/ jds.2009-2572.

Pösö, J., and E. A. Mäntysaari. 1996. Relationships between clinical mastitis, somatic cell score, and production for the first three lactations of Finnish Ayrshire. J. Dairy Sci. 79:1284-1291. https:// doi.org/10.3168/jds.S0022-0302(96)76483-4.

Ring, S. C., R. D. Evans, M. L. Doherty, and D. P. Berry. 2019. Genetic parameters for animal mortality in pasture-based, seasonalcalving dairy and beef herds. Livest. Sci. 219:10-16. https://doi .org/10.1016/j.livsci.2018.11.003.

Ring, S. C., J. McCarthy, M. M. Kelleher, M. L. Doherty, and D. P. Berry. 2018. Risk factors associated with animal mortality in pasture-based, seasonal-calving dairy and beef herds. J. Anim. Sci. 96:35-55. https://doi.org/10.1093/jas/skx072.

Robertson, A., and J. M. Rendel. 1950. The use of progeny testing with artificial insemination in dairy cattle. J. Genet. 50:21-31. https://doi.org/10.1007/BF02986791.

Togashi, K., and C. Y. Lin. 2006. Selection for milk production and persistency using eigenvectors of the random regression coefficient matrix. J. Dairy Sci. 89:4866-4873. https://doi.org/10.3168/jds .S0022-0302(06)72535-8.

Togashi, K., C. Y. Lin, Y. Atagi, K. Hagiya, J. Sato, and T. Nakanishi. 2008. Genetic characteristics of Japanese Holstein cows based on multiple-lactation random regression test-day animal models. Livest. Sci. 114:194-201. https://doi.org/10.1016/j.livsci.2007.04.023.

Torshizi, M. E., H. Farhangfar, and M. H. Mashhadi. 2017. Application of random regression models for genetic analysis of 305-d milk yield over different lactations of Iranian Holsteins. AsianAustralas. J. Anim. Sci. 30:1382-1387. https://doi.org/10.5713/ ajas.16.0885.

Visentin, G., S. McParland, M. De Marchi, A. McDermott, M. A. Fenelon, M. Penasa, and D. P. Berry. 2017. Processing characteristics of dairy cow milk are moderately heritable. J. Dairy Sci. 100:6343-6355. https://doi.org/10.3168/jds.2017-12642.

Walsh, S., F. Buckley, D. P. Berry, M. Rath, K. Pierce, N. Byrne, and P. Dillon. 2007. Effects of breed, feeding system, and parity on udder health and milking characteristics. J. Dairy Sci. 90:5767-5779. https://doi.org/10.3168/jds.2007-0389.

Williams, M. 2021a. Supplementary Table S1.docx. figshare. Figure. https://doi.org/10.6084/m9.figshare.16918429.

Williams, M. 2021b. Supplementary Table S2.docx. figshare. Figure. https://doi.org/10.6084/m9.figshare.16918498.v2.

Yang, R. Q., H. Y. Ren, L. R. Schaeffer, and S. Z. Xu. 2005. Estimation of genetic parameters for lactational milk yields using two-dimensional random regressions on parities and days in milk in Chinese Simmental cattle. J. Anim. Breed. Genet. 122:49-55. https://doi.org/10.1111/j.1439-0388.2004.00480.x.

Zarnecki, A., J. Jamrozik, and H. D. Norman. 1991. Comparison of ten Friesian strains in Poland for yield traits from first three parities. J. Dairy Sci. 74:2303-2308. https://doi.org/10.3168/jds.S0022 $-0302(91) 78403-8$

\section{ORCIDS}

M. Williams ำ https://orcid.org/0000-0001-7399-370X

R. D. Sleator @ https://orcid.org/0000-0001-5846-3938

C. P. Murphy 누 https://orcid.org/0000-0002-6064-2211

D. P. Berry @ https://orcid.org/0000-0003-4349-1447 